\title{
Bacteriostatic Effect of Copaiba Oil (Copaifera officinalis) against Streptococcus mutans
}

\author{
Fábio Alessandro PIERI ${ }^{1}$ \\ Maria Carolina Martins MUSSI ${ }^{2}$ \\ João Evangelista FIORINI ${ }^{3}$ \\ Maria Aparecida Scatamburlo MOREIRA ${ }^{1}$ \\ José Mauricio SCHNEEDORF ${ }^{4}$ \\ ${ }^{1} U F V$ - Federal University of Viçosa, Viçosa, $M G$, Brazil \\ ${ }^{2}$ Dental School, USP - University of São Paulo, São Paulo, SP, Brazil \\ ${ }^{3}$ José do Rosário Vellano University, Alfenas, MG, Brazil \\ ${ }^{4}$ UNIFAL - Federal University of Alfenas, Alfenas, MG, Brazil
}

\begin{abstract}
This study evaluated the inhibitory activity of copaiba oil (Copaifera officinalis) against the cariogenic microorganism, Streptococcus mutans. For such purpose, a minimum inhibition concentration test of copaiba oil against $S$. mutans was performed, using the serial dilution in broth technique, with a negative control, a positive control ( $0.12 \%$ chlorhexidine) and a $10 \%$ copaíba oil solution as a test. A minimum bactericidal concentration test with tubes presenting microbial inhibition was also conduced. In the minimum inhibitory concentration test, copaiba oil showed inhibition of bacterial growth at all concentrations tested up to $0.78 \mu \mathrm{L} / \mathrm{mL}$ of the $10 \%$ copaiba oil solution in the broth. In addition, the negative control had no inhibition, and the $0.12 \%$ chlorhexidine solution was effective up to $6.25 \mu \mathrm{L} / \mathrm{mL}$ in the broth. Copaiba oil showed a bacteriostatic activity against $S$. mutans at low concentrations, and could be a an option of phytotherapic agent to be used against cariogenic bacteria in the prevention of caries disease.
\end{abstract}

Key Words: dentistry, cariology, antimicrobials, phytotherapics.

\section{INTRODUCTION}

Teeth have several important functions such as mastication and speech (1). Dental caries affects patients, especially young children, so often causing significant loss of tooth structure $(2,3)$. Streptococcus mutans, is an important microorganism in the production of acid in the dental plaque $(4,5)$. The reduction of bacteria associated with caries in the dental plaque is a major preventive strategy and is also used as treatment resource (6).

Chlorhexidine has been used for decades as an antimicrobial agent in dentistry because it reduces the number of certain microorganisms $(2,4)$. However, its use should be restricted to a few days due to various side effects (7-9), and thus a substance with no collateral effects has been sought (10). Copaiba oil has been used for various purposes in traditional medicine therapies in Brazil $(11,12)$. Many of its properties, such as its antibacterial action, have been studied to include this phytotherapic agent as an option for the treatment of infections $(13,14)$.

The aim of this study was to evaluate the minimum inhibitory concentration (MIC) and the minimum bactericidal concentration (MBC) of copaiba oil against the cariogenic microorganism $S$. mutans.

\section{MATERIAL AND METHODS}

Three solutions were used. The negative control solution was prepared with $30 \mathrm{~mL}$ of alcohol $96^{\circ}, 20$ $\mathrm{mL}$ of propylene glycol, $20 \mathrm{~mL}$ of polyethylene glycol, $20 \mathrm{~mL}$ of glycerin and $10 \mathrm{~mL}$ of distilled water. The test solution consisted of negative control solution replacing distilled water by the same amount of copaiba oil. For the positive control solution, chlorhexidine was added to the negative control solution to reach a final concentration of $0.12 \%$. The microorganism used was a standard strain of S. mutans (ATCC 25175; American Type Culture

Correspondence: Profa. Dra. Maria Aparecida Scatamburlo Moreira, Avenida Peter Henry Rolfs, s/n, Campus Universitário, 36570-000 Viçosa, MG, Brasil. Tel: +55-31-3899-1457. e-mail: masm@ufv.br 
Collection, Manassas, VA, USA).

The MICs of the solutions against S. mutans were obtained as follows. Using the method of successive dilutions of solutions in liquid culture medium (15), the MICs were prepared with a series of 9 culture tubes containing brain hearth infusion (BHI) (Oxoid, Hampshire, UK) broth contaminated by $S$. mutans suspension in saline, adjusted to McFarland standard tube $\# 1$. The first 8 tubes of each series contained decreasing concentrations of one of the solutions $(100 \mu \mathrm{L} / \mathrm{mL}$ to $0.78 \mu \mathrm{L} / \mathrm{mL}$ ) and the 9 th tube had the control of bacterial growth without solution. The tubes were incubated at $35.5^{\circ} \mathrm{C}$ for $48 \mathrm{~h}$, and the inhibition was analyzed visually, recognizing the microbial growth by turbidity of the medium. The MIC was considered as the lowest concentration of the solution required to inhibit microbial growth without turbidity of the medium compared with a negative control without bacterial contamination.

The MBCs of the solutions against $S$. mutans were obtained as follows. For all tubes where the bacterium was inhibited in the MIC assay, using the method described by Phillipps (16), $0.1 \mathrm{~mL}$ aliquots of the contents were added to Petri dishes with $30 \mathrm{~mL}$ of BHI agar and incubated at $35.5^{\circ} \mathrm{C}$ for $24 \mathrm{~h}$. The dishes were analyzed visually to obtain the MBC, which was the highest dilution that killed $99.9 \%$ of bacteria, showing no growth on the Petri dish. All tests were performed in triplicate.

\section{RESULTS}

Regarding the MIC of solutions against $S$. mutans, the copaiba oil showed antimicrobial action against the bacterial strain at all tested concentrations, as indicated by the inhibition of growth and turbidity of the medium in all tubes. The MIC obtained in this test was $0.78 \mu \mathrm{L} /$ $\mathrm{mL}$ of solution in the culture medium. For the tubes with different concentrations of $0.12 \%$ chlorhexidine solution, inhibition of growth was observed in the first five tubes and the MIC obtained in this test was $6.25 \mu \mathrm{L} / \mathrm{mL}$ of solution in the culture medium. For other concentrations, microbial growth was identified by turbidity of the medium. The negative control solution had no inhibitory activity against $S$. mutans in the concentrations used.

Regarding the MBC of the solutions against $S$. mutans, all the dishes showed microbial growth after $24 \mathrm{~h}$, with no bactericidal action of any concentration of solutions against $S$. mutans. This indicates that the antimicrobial activity reported in the MIC test was bacteriostatic for both the copaiba oil and the positive control. The inoculum used for MIC was obtained by counting of viable bacteria in the Petri dishes, and the result was $1.6 \times 10^{6}$ colony forming units.

\section{DISCUSSION}

The antimicrobial activity of the copaiba oil was demonstrated in the MIC test, as this solution interfered with the microbial growth at all tested concentrations. This antimicrobial activity has been described by Pieri et al. (13) against other oral microorganisms such as $S$. pyogenes and $S$. salivarius. Copaiba oil has advantages over chlorhexidine because it is composed by several different substances that may have different interactions with the bacterial cell, reducing the development of resistant $S$. mutans strains. This justifies the use of only the ATCC strain in the present study, as field isolates are expected to have similar susceptibility to the antimicrobial effect of the Copaiba oil compared to the stardard strain.

This inhibition, however, seems to be bacteriostatic in nature, as none of the concentrations caused $99.9 \%$ of bacterial destruction in the MBC test. According Souza et al. (17), this bacteriostatic activity may be attributed to the copalic acid, a component of this oil. Packer and Luz (18) did not find microbial inhibition by copaiba oil against other bacterial strains as Staphylococcus aureus and Pseudomonas aeruginosa, with some strains having resistance to the oil's components.

Bacteriostatic activity of $0.12 \%$ chlorhexidine solution was found at concentrations between 100 and $6.75 \mu \mathrm{L} / \mathrm{mL}$. Swerts et al. (19) obtained similar results but also found inhibitory activity at lower chlorhexidine concentration.

The findings of the present study suggest that the copaiba oil has great potential for use against the growth of S. mutans, the main etiological agent of dental caries. In addition, even at low concentration, the copaiba oil was as effective as $0.12 \%$ chlorhexidine against this pathogen. However, further studies should be done involving analysis of the ideal concentration in the use of copaiba oil and the possible collateral effects of this phytotherapic agent in long-term treatment.

\section{RESUMO}

Este estudo avaliou a atividade inibitória do óleo de copaíba (Copaifera officinalis) contra o microrganismo cariogênico, Streptococcus mutans. Para isso, foi realizado um teste de concentração mínima inibitória do óleo de copaíba contra $S$. 
mutans, utilizando a técnica de diluição seriada em caldo, com um controle negativo, um controle positivo (clorexidina a $0,12 \%$ ) e uma solução de óleo de copaíba $10 \%$ como teste. Também foi conduzido um teste de concentração mínima bactericida com os tubos que apresentaram inibição microbiana. No teste de concentração inibitória mínima, o óleo de copaíba mostrou inibição do crescimento bacteriano em todas as concentrações testadas até $0,78 \mu \mathrm{L} / \mathrm{mL}$ da solução a $10 \%$ do óleo de copaíba no caldo. Além disso, o controle negativo não teve nenhuma inibição, e a solução de clorexidina $0,12 \%$ foi eficaz até $6,25 \mu \mathrm{L} / \mathrm{mL}$ no caldo. O óleo de copaíba mostrou uma atividade bacteriostática contra S. mutans em baixas concentrações, apresentando-se assim como uma opção de fitoterápico a ser utilizado contra bactérias cariogênicas na prevenção de cáries.

\section{REFERENCES}

1. Gotfredsen K, Walls AW. What dentition assures oral function? Clin Oral Implants Res 2007;18:34-45.

2. Tenovuo J, Häkkinen P, Paunio P, Emilson CG. Effects of chlorhexidine-fluoride gel treatments in mothers on the establishment of mutans streptococci in primary teeth and the development of dental caries in children. Caries Res 1992;26:275280.

3. Beltrán-Aguilar ED, Barker LK, Canto MT, Dye BA, Gooch BF, Griffin SO, et al.. Surveillance for dental caries, dental sealants, tooth retention, edentulism, and enamel fluorosis-United States, 1988-1994 and 1999-2002. MMWR Surveill Summ 2005;54:1-43.

4. Johansson E, Claesson R, Van Dijken JWV. Antibacterial effect of ozone on cariogenic bacterial species. J Dent 2009;37:449-453.

5. Li L, He J, Eckert R, Yarbrough D, Lux R, Anderson M, et al.. Design and characterization of an acid-activated antimicrobial peptide. Chem Biol Drug Des 2010;75:127-132.

6. Ten Cate JM. The need for antibacterial approaches to improve caries control. Adv Dent Res 2009;21:8-12.

7. Santos A. Evidence-based control of plaque and gingivitis. J Clin Periodontol 2003;30:13-16.

8. Lim KS, Kam PC. Chlorhexidine: pharmacology and clinical applications. Anaesth Intensive Care 2008;3:502-512.
9. Wikén Albertsson K, Persson A, Lingström P, van Dijken JW Effects of mouthrinses containing essential oils and alcohol-free chlorhexidine on human plaque acidogenicity. Clin Oral Investig 2010; $14: 107-112$.

10. Harvey CE, Thornsberry C, Miller BR, Shofer, F.S. Antimicrobial susceptibility of subgingival bacterial flora in dogs with gingivitis. J Vet Dent 1995;12:51-55.

11. Garrido AD, Lia RC, França SC, Da Silva JF, Astolfi-Filho S, Sousa-Neto MD. Laboratory evaluation of the physicochemical properties of a new root canal sealer based on Copaifera multijuga oil-resin. Int Endod J 2010;43:283-291.

12. Rosa PC, Mancini MN, Camargo SE, Garrido AD, Camargo $\mathrm{CH}$, Rode S de M. Dimensional alterations and solubility of new endodontic sealers. Braz Dent J 2010; 21:301-304.

13. Pieri FA, Mussi MC, Fiorini JE, Schneedorf JM. Clinical and microbiological effects of copaiba oil (Copaifera officinalis) on dental plaque forming bacteria in dogs. Arq Bras Med Vet Zoo 2010; 62:578-585.

14. Pieri FA, Mansur R, Galvão NN, Nero LA, Moreira, MA. Antimicrobial activity of autoclaved and non autoclaved copaiba oil on Listeria monocytogenes. Cienc Rural 2010; 40:1797-1801.

15. Andrews JM. Determination of minimum inhibitory concentrations. J Antimicrob Chemoth 2001;48:5-16.

16. Phillips I. A guide to sensitivity testing. J Antimicrob Chemoth 1991;27:1-50.

17. Souza AB, Martins CH, Souza MG, Furtado NA, Heleno VC, Sousa JB et al.. Antimicrobial activity of terpenoids from Copaifera langsdorffii Desf. against cariogenic bacteria. Phytother Res 2011;25:215-220.

18. Packer JF, Luz MM. Evaluation and research method for natural products inhibitory activity. Rev Bras Farmacogn 2007;17:102107.

19. Swerts MS, Costa AM, Fiorini JE. Effect of the associated solution of chlorhexidine and propolis on the inhibition of adherence by Streptococcus spp. Rev Int Periodont Clin 2005;2:10-16.

Received January 14, 2011

Accepted November 17, 2011 